Available online at http://journal.stkip-andi-matappa.ac.id/index.php/histogram/index

Histogram: Jurnal Pendidikan Matematika 4(2)., 2020, 398 - 408

\title{
ANALISIS DESKRIPTIF MODEL PEMBELAJARAN KOOPERATIF TIPE JIGSAW DALAM UPAYA PENINGKATAN MOTIVASI BELAJAR
}

\author{
Yurike $^{1)}$, Wahyudi' ${ }^{2}$ \\ 1,2 Universitas Muhammadiyah Ponorogo \\ * Corresponding Author.Email :yurike806@gmail.com \\ Received: 25 Juli 2020; Revised: 15 September 2020 ; Accepted: 30 September 2020
}

\section{ABSTRAK}

Motivasi belajar adalah sebuah dorongan yang memicu siswa untuk belajar supaya proses pembelajaran mengarah pada tujuan yang ingin tercapai. Tanpa adanya motivasi pada siswa maka tujuan pembelajaran sulit teraih. Model pembelajaran kooperatif tipe jigsaw bertujuan untuk menambah daya berpikir siswa, rasa tanggung jawab dan keingintahuan yang lebih tinggi. Model pembelajaran kooperatif tipe jigsaw merupakan sistem pembelajaran berkelompok yang memperhatikan pemerataan seperti gender dan intelektual. Setiap anggota kelompok saling membutuhkan serta memiliki tanggung jawab menguasai materi bersama kelompok ahli dan menyampaikan hasil diskusi pada kelompok asal kemudian mereka bergantian dengan anggota kelompok lain. Tanggung jawab dalam menguasai materi setiap individu ini akan mendorong siswa untuk belajar agar dapat menguasai materinya. Jenis pengumpulan data penelitian ini adalah kajian pustaka yang tujuannya untuk mengetahui bagaimana model pembelajaran kooperatif tipe jigsaw untuk upaya peningkatan motivasi belajar matematika. Teknik pengumpulan data diperoleh dari beberapa sumber yang relevan terkait dengan penelitian yang sedang diteliti. Dari beberapa sumber yang diperoleh menyatakan bahwa hasil penelitian penerapan model pembelajaran kooperatif tipe jigsaw dalam kegiatan pembelajaran dikelas dapat membantu siswa meningkatkan motivasi belajar

Kata Kunci: motivasi belajar, pembelajaran kooperatif, jigsaw

\section{ABSTRACT}

Motivation to learn is an encouragement that triggers students to learn so that the learning process leads to the goals to be achieved. Without motivation in students, the learning objectives are difficult to achieve. The type of jigsaw cooperative learning model aims to increase students' thinking power, a higher sense of responsibility and curiosity. The jigsaw cooperative learning model is a group learning system that pays attention to equity such as gender and intellectuality. Each group member needs each other and has the responsibility of mastering the material with the expert group and presenting the results of the discussion to the home group then they take turns with other group members. The responsibility for mastering the material for each individual will encourage students to learn in order to master the material. The type of data collection in this research is literature review which aims to find out how the jigsaw cooperative learning model is used to increase motivation to learn mathematics. Data collection techniques were obtained from several relevant sources related to the research being studied. From several sources obtained, it is stated that the results of research on the application of the type of jigsaw cooperative learning model in classroom learning activities can help students increase learning motivation

Keyword: learning motivation, cooperative learning, jigsaw

How to Cite: Yurike., \& Wahyudi. (2020). Analisis Deskriptif Model Pembelajaran Kooperatif Tipe Jigsaw Dalam Upaya Peningkatan Motivasi Belajar. Histogram: Jurnal Pendidikan Matematika, $4(2), \quad 398 \quad$ - $\quad 408, \quad$ doi: http://dx.doi.org/10.31100/histogram.v4i2.684

Permalink/DOI: http://dx.doi.org/10.31100/histogram.v4i2.684

\section{PENDAHULUAN}

Dalam aktivitas belajar dikelas terjadi proses pemberian ilmu dari guru kepada siswa agar dikuasai dengan baik yang dinamakan dengan pembelajaran. Menurut Copyright $($ 2020, THE AUTHOR (S). This article distributed under the CC-BY-SA-license. 


\section{Histogram: Jurnal Pendidikan Matematika, 4 (2), 2020 - 399 \\ Wahyudi $^{*}$, Yurike ${ }^{2}$}

Komalasari dan Kokom (2013: 3) pembelajaran merupakan proses membelajarkan siswa yang direncakan, dilaksanakan, dan dievaluasi agar tujuan dalam pembelajaran dapat tercapai. Sedangkan Hamalik (2014: 57) menyatakan pembelajaran adalah kombinasi yang meliputi unsur manusiawi, fasilitas, material, perlengkapan, dan prosedur yang berpengaruh terhadap pencapaian tujuan pembelajaran.

Tujuan pembelajaran dapat tercapai apabila siswa punya keinginan menguasai materi pembelajaran awal sampai akhir. Sesuai pendapat Akbar dkk (2017: 1) yang menyatakan bahwa dalam pembelajaran, tujuan pembelajaran akan tercapai apabila terdapat motivasi dalam diri siswa. Menurut Leksonowati (2019: 15) motivasi ini diartikan sebagai keinginan, hasrat, dorongan, kemauan, usaha, tekad, maksud dan citacita dalam mencapai prestasi. Sedangkan menurut Haryati (2012: 34) motivasi ini adalah faktor yang sangat menentukan baik buruknya prestasi siswa dalam belajar. Jika motivasi pada siswa tinggi maka hasil belajar yang dan tujuan pembelajaran dapat tercapai secara optimal. Menurut Irawati (2014: 90) motivasi dan rasa percaya diri dalam kegiatan belajar akan meningkat apabila saat pembelajaran di kelas lebih mengedepankan kerja sama. Dengan demikian perlu adanya upaya dari guru untuk membantu siswa meningkatkan motivasi belajar. Salah satu upaya yang dapat dilakukan adalah dengan melakukan pembaruan model pembelajaran yang digunakan saat pembelajaran.

Menurut Leksonowati (2019: 20) pembelajaran kooperatif mempunyai arti pembelajaran dengan sistem berkelompok atau belajar diskusi yang memperhatikan unsur ketegantungan positif antar individu, saling berinteraksi antar anggota kelompok, dan saling bertanggung jawab dalam memecahkan masalah. Hal ini memiliki tujuan supaya dalam pembelajaran di kelas siswa lebih aktif. Aship (2014: 10) berpendapat bahwa model pembelajaran dengan membagi siswa menjadi beberapa kelompok tidak besar yang memfokuskan proses belajar siswa pada kegiatan berkelompok disebut model pembelajaran kooperatif tipe jigsaw. Rusman (2012: 218) menyatakan bahwa model kooperatif tipe jigsaw adalah pembelajaran berkelompok yang saling ketergantungan positif dan bertanggung jawab secara mandiri. Model pembelajaran kooperatif tipe jigsaw merupakan salah satu model pembelajaraan kooperatif yang mampu meningkatkan motivasi belajar pada siswa karena mengajarkan siswa untuk bertanggung jawab dalam menguasai materi yang diberikan oleh guru. Seran (2016:12) juga menyatakan bahwa salah satu kelebihan model pembelajaran kooperatif tipe jigsaw adalah siswa dapat meningkatkan motivasi belajar. 


\section{Histogram: Jurnal Pendidikan Matematika, 4 (2), 2020 - 400 \\ Wahyudi $^{*}$, Yurike ${ }^{2}$}

\section{METODE PENELITIAN}

Jenis penelitian ini adalah penelitian kajian pustaka atau studi kepustakaan. Menurut Masdariah, dkk (2018: 553) berpendapat bahwa penelitian kajian pustaka adalah cara dalam menghimpun data-data atau sumber yang berhubungan dengan topik yang akan diteliti. Menurut (Sanusi, 2016: 32) data-data atau sumber dalam penelitian kajian pustaka dapat diperoleh dari buku, jurnal, skripsi, dokumentasi, tesis, desertasi dan internet yang relavan. (Hendra, 2012:49) menyatakan studi pustaka adalah penelitian yang dilakukan oleh peneliti dengan mengumpulkan data-data yang berasal dari buku, majalah, liflet yang berhubungan dengan masalah dan tujuan penelitian. Dengan demikian, dapat diketahui bahwa metode kajian pustaka ini adalah penelitian yang dilakukan dengan mengumpulkan berbagai sumber data dari berbagai sumber yang relevan yang bertujuan untuk memecahkan permasalahan yang sedang diteliti.

\section{HASIL DAN PEMBAHASAN}

\section{A. Model pembelajaran kooperatif tipe jigsaw}

Menurut Hamdani (2011: 30) pembelajaran kooperatif merupakan serangkaian aktivitas belajar siswa yang memiliki tujuan untuk mencapai keinginan dan harapan yang berbentuk kelompok. Pembelajaran kooperatif ini pembelajaran yang mampu merangsang motivasi, kemandirian, dan bakat pada diri siswa melalui kerjasama dengan kelompok. Tsay \& Brady (2010: 85) menyatakan bahwa berdasarkan hasil beberapa penelitian di bidang pendidikan, penerapan model pembelajaran ini melibatkan siswa pada proses pembelajaran, sehingga motivasi serta hasil belajar siswa mampu ditingkatkan. Berdasarkan hasil penelitian Seran (2016: 83) menyatakan bahwa motivasi belajar siswa meningkat dengan menerapkan model pembelajaran kooperatif tipe jigsaw berdasarkan angket yang diberikan diperoleh presentase dari $60 \%$ menjadi $80 \%$. Hasil penelitian Aship (2014:49) juga menyatakan motivasi belajar siswa meningkat dengan menerapkan model pembelajaran kooperatif tipe jigsaw berdasarkan t-hitung 5,374 $>$ t-tabel 1,333 dan nilai probabilitas $(\mathrm{sig})<a=0.05$. Isjoni (2009: 15) menyatakan pembelajaran kooperatif adalah model pembelajaran dimana siswa bekerja dalam sebuah kelompok kecil yang terdiri dari 5 anggota yang heterogen.

Menurut Nurhadi, dkk (2004: 64) pembelajaran kooperatif memuat beberapa unsur penting yaitu sama-sama ketergantungan positif, terjadi interaksi sesama siswa, keterampilan interpersonal, adanya tanggungjawab pada setiap siswa, dan proses kegiatan secara kelompok. Suatu pembelajaran yang terbentuk dari beberapa kelompok yang 


\section{Histogram: Jurnal Pendidikan Matematika, 4 (2), 2020 - 401 \\ Wahyudi $^{*}$, Yurike ${ }^{2}$}

dibagi secara heterogen dimana antar siswa sama-sama ketergantungan positif sehingga siswa lebih terangsang untuk giat belajar merupakan pembelajaran kooperatif. Pada model pembelajaran kooperatif peran guru menjadi fasilitator saja dan siswa diminta untuk menyelesaikan persoalan yang diberikan guru dengan cara bekerja team. Dalam proses berkelompok ini, siswa berlatih saling menyalurkan pendapat, berbagi pengetahuan, dan berpikir kritis.

Hertiavi, dkk (2010: 54) mengungkapkan bahwa model pembelajaran tipe jigsaw yaitu salah satu model dalam pembelajaran kooperatif dengan aturan berkelompok heterogen. Sumarsih \& Pardimin (2017: 125) berpendapat bahwa model pembelajaran tipe jigsaw lebih mudah diterapkan serta melibatkan siswa untuk beraktifitas. Dalam model pembelajaran ini terdapat kelompok asal yang beranggotakan empat atau lima anggota dan kemudian setiap individu dari kelompok asal akan dibentuk kelompok baru bernama kelompok ahli. Model pembelajaran tipe jigsaw ini dapat dikatakan sebagai strategi belajar yang melibatkan siswa untuk saling berbagi pengetahuan dengan siswa lainnya. Menurut Mbaco (2013: 28) pada proses pembelajaran jigsaw, motivasi intrinsik dan minat belajar terlihat lebih kuat, kompeten, dan percaya terhadap diri sendiri. Hasil seperti itu terjadi karena, siswa lebih terlibat dalam proses pembelajaran. Adams (2013: 65) berpendapat bahwa implementasi model jigsaw di kelas menjadikan siswa lebih percaya diri dengan kemampuannya dan lebih semangat untuk bersekolah.

Tahapan dalam model jigsaw menurut Hanafiah \& Suhana (2010: 44) yaitu siswa dibentuk berkelompok terdiri dari empat sampai lima siswa (kelompok asal), setiap siswa akan disediakan materi atau masalah yang berbeda dengan anggota kelompok lainnya, setiap siswa yang memperoleh bagian materi atau masalah yang sama dengan siswa kelompok lain bertemu, kemudian membentuk kelompok yang dinamakan kelompok ahli untuk sama-sama mempelajari dan mendiskusikan materi tersebut, selesai mempelajari dan mendiskusikan materi, setiap individu akan kembali ke kelompok asalnya dan saling menyampaikan materi yang sudah dikuasai kepada anggota satu kelompok secara bergantian dengan anggota kelompoknya, selanjutnya kelompok ahli mempresentasikan mengenai hasil diskusi mereka secara bergantian dengan kelompok lain, guru melaksanakan evaluasi dan penutupan. Kelebihan dari model jigsaw ini menurut Seran (2016: 201) yaitu siswa yang memiliki kompetensi berbeda-beda, saling terjalin hubungan positif, bimbingan antar kelompok terlaksana, saling menerima pendapat yang berbeda-beda, materi lebih mudah didalami dan siswa selalu termotivasi belajar di kelas. 


\section{Histogram: Jurnal Pendidikan Matematika, 4 (2), 2020 - 402 \\ Wahyudi $^{*}$, Yurike ${ }^{2}$}

Pada pembelajaran ini akan dibentuk kelompok ahli yang bertanggung jawab dan berperan mendalami materi yang diperoleh, setelah dirasa paham maka setiap individu kembali dan menyampaikan materi yang sudah dipahami pada kelompok asalnya. Dengan ini, siswa belajar tentang bertanggung jawab terhadap pemahaman materi dan akhirnya siswa termotivasi untuk mendalami materi dengan baik. Pada tipe jigsaw ini, siswa bertukar pikiran dan saling menghargai pendapat. Sifat inilah yang berdampak positif untuk kehidupan sosial. Hal ini juga dirasakan oleh guru karena siswa lebih mudah mendalami dan menguasai materi dan guru hanya sebagai fasilitator.

\section{B. Motivasi belajar}

Menurut Samsudin (2012: 126) motivasi adalah proses yang memiliki pengaruh serta memberikan dorongan pada individu atau kelompok kerja agar yang bersangkutan memiliki keinginan untuk bertindak terhadap sesuatu yang telah ditentukan. Menurut Hamdu \& Agustina (2011: 83) motivasi merupakan cara sadar yang menggerakkan dan membimbing perilaku agar seseorang terdorong untuk mengerjakan suatu tindakan dalam menggapai keinginan sesuai dengan harapan. Untuk itu, pada proses belajar siswa membutuhkan motivasi belajar sehingga dapat mencapai tujuan pembelajaran dan menjadikan pembelajaran yang efektif. Menurut Pustpitasari \& Dewi (2012: 60) motivasi belajar merupakan usaha siswa dalam diri sendiri untuk belajar yang mengarah ke tujuan yang dikehendakinya tercapai. Dimyati \& Mujiono (2010: 99) berpendapat bahwa motivasi belajar merupakan hal yang penting karena mampu menyadarkan keadaan siswa saat mulai belajar, proses pembelajaran, hasil belajar yang diperoleh, menginformasikan tentang kemampuan usaha belajar yang akan dibandingkan dengan temannya, membimbing aktivitas belajar, dapat membesarkan semangat belajar dan menyadarkan bahwa adanya tahapan dalam proses belajar. Berdasarkan hasil penelitian Aini(2016:3) bahwa prsentase motivasi siswa sebesar 77,29\% dengan kriteria tinggi, ini karena siswa mempunyai minat dan bersungguh-sungguh dalam kegiatann pembelajaran. Motivasi belajar yang dimiliki siswa mampu meningkatkan hasil dan prestasi belajar.

Terdapat dua macam motivasi belajar yaitu motivasi intrinsik dan ekstrinsik. Motivasi instrinsik adalah aktivitas belajar yang diawali dan diteruskan berdasarkan pendalaman sesuai keperluan dan keinginan yang erat kaitannya dengan proses belajar. Motivasi intrinsik tumbuh sesuai dengan keinginan diri siswa bukan rangsangan dari luar. Motivasi ekstrinsik adalah lawan dari motivasi instrinsik yaitu motivasi yang ada karena pemicu dari luar yang mendorong siswa tersebut. Misalnya siswa rajin belajar karena akan melaksanakan ujian (Aship, 2014: 20). 


\section{Histogram: Jurnal Pendidikan Matematika, 4 (2), 2020 - 403 \\ Wahyudi $^{*}$, Yurike ${ }^{2}$}

Terdapat delapan indikator motivasi belajar menurut Sardiman (2008: 83) yaitu mempunyai kepercayaan kuat, senang saat menyelesaikan persoalan, mampu mempertahankan pendapat, malas dengan tugas rutin, suka bekerja mandiri, menandakan minat belajar, ulet dalam menghadapi kesulitan, dan tekun menghadapi tugas. Menurut Ramayulis (2002: 33) motivasi mempunyai fungsi yaitu membantu melengkapi keinginan siswa akan hasil jangka pendek maupun jangka panjang, fokus pada masalah yang berkaitan dengan tujuan yang ingin dicapai, dan selalu terdorong memiliki minat dan siaga. Oleh karena itu, motivasi belajar dapat diartikan sebuah kemauan diri sendiri yang mempengaruhi kesuksesan siswa dalam belajar. Siswa yang mempunyai keinginan belajar tinggi, maka akan mencapai hasil optimal dan sebaliknya. Dengan ini, hasil belajar yang optimal karena adanya motivasi belajar dari diri siswa itu sendiri.

\section{Gambaran model pembelajaran kooperatif tipe jigsaw untuk upaya peningkatan motivasi belajar matematika siswa}

Keberhasilan proses pembelajaran apabila siswa termotivasi untuk belajar matematika. Dari pihak guru harus memiliki pembaruan dalam melakukan proses pembelajaran yang menjadikan siswa aktif berpartisipasi dan tidak bosan di kelas saat pembelajaran berlangsung. Nisa (2011: 38) berpendapat bahwa siswa yang memiliki pengetahuan yang mendalam akan menunjukan partisipasi aktif dan kreatif. Pembelajaran dengan sistem berkelompok selalu mengedepankan kerjasama dan saling berbagi sesama anggota kelompok. Menurut Irawati (2014: 90) motivasi dan rasa percaya diri dalam kegiatan belajar akan meningkat apabila saat pembelajaran di kelas lebih mengedepankan kerja sama.

Sesuai dengan pendapat Seran (2016: 201) sebelumnya bahwa salah satu kelebihan model pembelajaran kooperatif tipe jigsaw mampu membantu siswa meningkatkan motivasi belajar di kelas. Menurut Jati (2016: 3.196) siswa akan memiliki rasa tanggungjawab dalam penguasan materi yang diberikan dan menyampaikan kembali secara bergantian dengan anggota kelompok lain. Setiap siswa akan menguasai materi bersama kelompok ahlinya dengan menemukan beberapa sumber yang berkaitan dengan materi untuk memudahkan mereka dalam menguasai materi sehingga semua siswa akan aktif dikelas.

Setiap langkah-langkah dari model pembelajaran kooperatif tipe jigsaw untuk upaya peningkatan motivasi belajar digambarkan sebagai berikut : (1) Langkah pertama siswa dibentuk menjadi beberapa kelompok kecil (kelompok asal) yang akan menjadikan siswa memiliki minat belajar dan malas terhadap tugas tidak non rutin. Kegiatan kerja 


\section{Histogram: Jurnal Pendidikan Matematika, 4 (2), 2020 - 404 \\ Wahyudi $^{*}$, Yurike ${ }^{2}$}

sama dalam pembelajaran berkelompok akan mejadikan siswa ikut berperan aktif di kelas. Hal ini sesuai hasil penelitian Aini, dkk (2016: 7) kriteria indikator cepat bosan pada tugas tidak non rutin meningkat dengan presentasi rata-rata $76,71 \%$ dengan kriteria tinggi, ini karena siswa senang mengikuti pelajaran apabila dalam pembelajaran dibentuk kelompok; (2) Langkah kedua menjadikan siswa lebih menyukai belajar mandiri senang menyelesaikan masalah, tekun menghadapi tugas, ulet menghadapai kesulitan dan menandakan minat belajar. Pemberian tugas secara individu pada siswa akan menimbulkan dorongan yang kuat dan tanggung jawab mempelajari materi secara individu. Sejalan dengan pendapat Ashari, dkk (2011:17) menyatakan agar proses kemandirian siswa terwujud perlu sebuah aktivitas serta siswa dijadikan sebagai subyek yang tidak pasif; (3) Langkah ketiga menjadikan siswa mampu mempertahankan pendapat, memiliki kepercayaan kuat, senang menyelesaikan persoalan, dan tekun menghadapi tugas, dan ulet menghadapi kesulitan. Dalam kegiatan berdiskusi bersama kelompok, siswa akan berperan aktif dan tekun dalam menyelesaikan masalah serta siswa akan belajar mengungkapkan dan mempertahankan gagasan atau pendapatnya yang didukung dengan kemampuan memahami materi. Sesuai dengan pendapat Dongoran (2015:101) tujuan dalam berdiskusi agar siswa terlibat dalam proses interaksi dan siswa lebih aktif dalam proses bertukar pikiran sehingga dapat meningkatkan motivasi belajar siswa; (5) Langkah keempat menjadikan siswa memperlihatkan minat belajar, tekun menghadapi tugas, memiliki keyakinan yang kuat, ulet menghadapi kesulitan, dan senang menyelesaikan masalah. Penyapaian materi pada kelompok asal dapat menunjukan minat siswa dalam menyampaikan materi, memperhatikan, dan menanggapi penjelasan dari teman. Menurut Akbar, dkk (2017: 4) siswa yang terbiasa belajar akan lebih mudah menjawab, mempertahankan pendapatnya, dan siswa juga senang bertanya untuk memperoleh informasi; (6) Langkah kelima menjadikan siswa memperlihatkan minat belajar, tekun menghadapi tugas, mampu mempertahankan pendapat, memiliki kepercayaan kuat, ulet menghadapi kesulitan, senang menyelesaikan persoalan. Kegiatan presentasi membuat siswa belajar percaya pada kemampuanya dalam menyampaikan materi dan antusias dalam berdiskusi. Hal ini sejalan dengan Nasution (2015: 125) yang berpendapat siswa dapat mempertahankan pendapatnya apabila siswa mempunyai rasa percaya terhadap diri sendiri yang tinggi; (7) Langkah keenam menjadikan siswa memperlihatkan minat belajar, senang menyelesaikan persoalan, dan dapat mempertahankan keyakinanya. Dalam evaluasi pembelajaran siswa akan aktif bertukar pikiran dalam menyimpulkan hasil pembelajaran yang telah berlangsung. Hal ini sesuai 


\section{Histogram: Jurnal Pendidikan Matematika, 4 (2), 2020 - 405 \\ Wahyudi $^{*}$, Yurike ${ }^{2}$}

hasil penelitian Nisa (2011:38) bahwa siswa yang belajar kreatif tidak mudah terpengaruh sehingga akan meningkatkan keyakinannya dan guru harus mampu mengevaluasi kejadian untuk dilakukan inovasi. Sesuai dengan angket yang diberikan menunjukkan presentase $80 \%$ dengan kriteria tinggi apabila siswa aktif dan kreatif dalm pembelajaran.

Berdasarkan uraian diatas dapat disimpulkan bahwa adanya hubungan antara langkah-langkah penerapan model pembelajaran kooperatif tipe jigsaw dengan motivasi belajar siswa. Dengan demikian model pembelajaran kooperatif tipe jigsaw dapat diterapkan untuk membantu meningkatkan motivasi belajar matematika. Hal tersebut dapat digambarkan melalui table 1 .

Tabel 1. Langkah Model Pembelajaran Kooperatif Tipe Jigsaw Untuk Upaya Peningkatan Motivasi Belajar Matematika

\begin{tabular}{|c|c|c|c|}
\hline No. & Langkah-Langkah & Indikator Motivasi Belajar & Alasan \\
\hline 1. & $\begin{array}{lr}\text { Siswa } & \text { dibentuk } \\
\text { menjadi } & \text { kelompok } \\
\text { asal } & \end{array}$ & $\begin{array}{l}\text { a) Menandakan minat belajar } \\
\text { b) Malas terhadap tugas tidak } \\
\text { nonrutin }\end{array}$ & $\begin{array}{l}\text { Tahapan ini mampu } \\
\text { membangun motivasi } \\
\text { belajar matematika dan } \\
\text { melibatkan siswa aktif di } \\
\text { kelas }\end{array}$ \\
\hline 2. & $\begin{array}{l}\text { Masing-masing } \\
\text { individu diberi } \\
\text { materi yang } \\
\text { berbeda dengan } \\
\text { anggota } \\
\text { kelompoknya }\end{array}$ & $\begin{array}{l}\text { a) Menyukai bekerja secara } \\
\text { mandiri } \\
\text { b) Senang menyelesaikan } \\
\text { masalah } \\
\text { c) Tekun menghadapai tugas } \\
\text { d) Ulet menghadapi kesulitan } \\
\text { e) Menandakan minat belajar }\end{array}$ & $\begin{array}{l}\text { Tahap ini berperan dalam } \\
\text { peningkatan motivasi } \\
\text { belajar matematika } \\
\text { dengan adanya dorongan } \\
\text { kuat dalam kreatif dan } \\
\text { menemukan sendiri. } \\
\text { Siswa memiliki rasa } \\
\text { tanggungjawab dalam } \\
\text { mempelajari materi secara } \\
\text { individu }\end{array}$ \\
\hline 3. & $\begin{array}{l}\text { Setiap siswa yang } \\
\text { memperoleh bagian } \\
\text { materi atau masalah } \\
\text { yang sama dengan } \\
\text { anggota kelompok } \\
\text { lain bertemu dan }\end{array}$ & $\begin{array}{l}\text { a) Mampu mempertahankan } \\
\text { pendapat } \\
\text { b) Memiliki kepercayaan kuat } \\
\text { c) Senang menyelesaikan } \\
\text { persoalan } \\
\text { d) Tekun menghadapi tugas }\end{array}$ & $\begin{array}{l}\text { Pada tahapan ini mampu } \\
\text { memotivasi siswa untuk } \\
\text { saling aktif dalam } \\
\text { mengungkapkan pendapat } \\
\text { dan saat berdiskusi. Siswa } \\
\text { memiliki motivasi kuat }\end{array}$ \\
\hline
\end{tabular}


Histogram: Jurnal Pendidikan Matematika, 4 (2), 2020 - 406

Wahyudi $^{*}$, Yurike ${ }^{2}$

\begin{tabular}{|c|c|c|c|}
\hline No. & Langkah-Langkah & Indikator Motivasi Belajar & Alasan \\
\hline & $\begin{array}{l}\text { membuat kelompok } \\
\text { baru (kelompok } \\
\text { ahli) untuk sama- } \\
\text { sama mempelajari } \\
\text { dan mendiskusikan } \\
\text { materi atau masalah } \\
\text { yang diperoleh }\end{array}$ & e) Ulet & $\begin{array}{l}\text { dalam mengutarakan dan } \\
\text { mempertahakan pendapat } \\
\text { yang didukung dengan } \\
\text { kemampuan memahami } \\
\text { materi yang baik }\end{array}$ \\
\hline 4. & $\begin{array}{l}\text { Setelah poin } 3, \\
\text { siswa kembali dan } \\
\text { mendiskusikan } \\
\text { materi yang telah } \\
\text { diperoleh ke } \\
\text { kelompok asal } \\
\text { secara bergantian } \\
\text { antar anggota } \\
\text { kelompok }\end{array}$ & $\begin{array}{l}\text { a) Memperlihatkan minat } \\
\text { belajar } \\
\text { b) Tekun menghadapi tugas } \\
\text { c) Memiliki keyakinan yang } \\
\text { kuat } \\
\text { d) Ulet menghadapi kesulitan } \\
\text { e) Senang menyelesaikan } \\
\text { masalah }\end{array}$ & $\begin{array}{l}\text { Setiap siswa termotivasi } \\
\text { untuk menjelaskan materi } \\
\text { di depan temannya. Minat } \\
\text { belajar ditunjukkan dari } \\
\text { siswa memperhatikan } \\
\text { teman yang lain dan } \\
\text { menanggapi penjelasan } \\
\text { dari teman }\end{array}$ \\
\hline 5. & $\begin{array}{l}\text { Masing-masing } \\
\text { kelompok ahli } \\
\text { mempresentasikan } \\
\text { hasil diskusinya }\end{array}$ & $\begin{array}{l}\text { a) Menandakan minat belajar } \\
\text { b) Tekun menghadapi tugas } \\
\text { c) Mampu mempertahankan } \\
\text { pendapat } \\
\text { d) Memiliki kepercayaan kuat } \\
\text { e) Ulet menghadapi kesulitan } \\
\text { f) Senang menyelesaikan } \\
\text { persoalan }\end{array}$ & $\begin{array}{l}\text { Siswa termotivasi } \\
\text { menyampaikan materi di } \\
\text { kelompok ahli. Siswa } \\
\text { percaya lebih percaya diri } \\
\text { dan menunjukkan minat } \\
\text { belajarnya saat antusias } \\
\text { berdiskusi } \\
\text { kelompok }\end{array}$ \\
\hline 6. & $\begin{array}{l}\text { Evaluasi } \\
\text { pembelajaran } \\
\text { bersama }\end{array}$ & $\begin{array}{l}\text { a) Memperlihatkan minat } \\
\text { belajar } \\
\text { b) Senang menyelesaikan } \\
\text { persoalan } \\
\text { c) Dapat mempertahankan } \\
\text { keyakinanya }\end{array}$ & $\begin{array}{l}\text { Siswa aktif dan saling } \\
\text { bertukar kesimpulan dari } \\
\text { pembelajaran yang telah } \\
\text { berlangsung yang tak } \\
\text { lepas dari bimbingan guru }\end{array}$ \\
\hline 7. & Penutup & - & - \\
\hline
\end{tabular}




\section{Histogram: Jurnal Pendidikan Matematika, 4 (2), 2020 - 407 \\ Wahyudi $^{*}$, Yurike ${ }^{2}$}

\section{KESIMPULAN DAN SARAN}

Model pembelajaran kooperatif tipe jigsaw adalah suatu pembelajatan berkelompok heterogen yang setiap siswa mempelajari dan mendiskusikan materi yang sudah dibagi sebelumnya dengan kelompok ahli. Setelah itu, anggota kelompok akan bertanggung jawab menyampaikan kembali materi yang telah didiskusikan pada kelompok asal secara bergantian. Model yang mengajarkan siswa menjadi lebih percaya diri dengan kemampuannya untuk berpikir dan berusaha mendapatkan informasi dari sumber lainnya serta saling belajar antar siswa adalah model pembelajaran kooperatif tipe jigsaw. Dalam model ini, siswa juga didorong belajar mengungkapkan gagasannya, melatih siswa untuk mempertahankan pendapatnya, saling tukar pendapat, serta mendorong siswa berkemampuan rendah memahami materi dengan dibantu temannya yang sudah paham. Dengan ini, siswa akan lebih termotivasi dalam proses pembelajaran matematika. Dengan demikian artikel model pembelajaran kooperatif tipe jigsaw ini dapat dijadikan referensi untuk upaya peningkatan motivasi belajar matematika. Artikel ini juga dapat dugunakan referensi untuk penelitian selanjutnya yang lebih baik.

\section{DAFTAR PUSTAKA}

Adam, F.H. (2013). Using Jigsaw Technique as an Effective Way of Promotion Cooperative Learning Among Primary Six Pupils in Fijai. International Journal of Education and Practice, 1(6), 64-74.

Aship, M. (2014). Penerapan Model Pembelajaran Kooperatif Tipe Jigsaw untuk Meningkatkan Motivasi Belajar Siswa pada Mata Pelajaran PAI di SMP Muhammadiyah 8 Jakarta. Jakarta: Skripsi Fakultas Ilmu Tarbiyah dan Keguruan UIN Syarif Hidayatullah.

Dimyati dan Mujiono. (2010). Belajar dan Pembelajaran. Jakarta: PT. Rineka Cipta.

Hamdani. (2011). Strategi Belajar Mengajar. Bandung: CV. Pustaka Setia.

Hamdu, G. \& Agustina, L. (2011). Pengaruh Mtoivasi Belajar Siswa Terhadap Prestasi Belajar IPA di Sekolah Dasar. Jurnal Penelitian Pendidikan, 12(1), 81-86.

Haryani, F. (2012). Meningkatkan Mtoivasi dan Pemahaman Konsep Perbandingan Fungsi Trigonometri Melalui Pembelajaran Jigsaw di SMA Negeri Kota Jambi. Jurnal Pendidikan Matematika dan Ilmu Pengetahuan Umum, 1(1), 33-37.

Hendra, V. (2012). Studi Pustaka (Online). http://Repositori.ui.edu. Diakses pada tanggal 13 Juli 2020 Pukul 20.00 WIB.

Hertiavi, M.D., Langlang, H. \& Khanafiyah, S. (2010). Penerapan Model Pembelajaran Kooperatif Tipe Jigswa untuk Peningkatan Kemampuan Pemecahan Masalah Siswa SMP. Jurnal Pendidikan Fisika Indonesia, 6(1), 53-57.

Irawati, I. (2014). Penerapan Metode Jigsaw untuk Meningkatkan Motivasi dan Prestasi belajar Fisika Kelas XIII MAN 15 Jakarta. In Prosiding Seminar Nasional Fisika (EJournal), 3, 89-93.

Leksonowati, N. (2019). Efektivitas Penerapan Model Pembelajaran Tutor Sebaya dan Jigsaw Terhadap Hasil Belajar Ditinjau dari Motivasi Belajar dan Kecerdasan Emosional Siswa. Jurnal Dimensi Pendidikan dan Pembelajaran, 7(1), 18-24. 


\section{Histogram: Jurnal Pendidikan Matematika, 4 (2), 2020 - 408 \\ Wahyudi $^{*}$, Yurike ${ }^{2}$}

Masdariah, M., Nurhayati, B., \& Rachmawati, R. (2018). Kajian Deskripsi Model Discovery Learning dalam Meningkatkan Motivasi Belajar, Aktivitas Belajar, dan Hasil Belajar Peserta Didik. Makalah pada Seminar Nasional Belajar dan Pembelajarannya Tahun 2018. Makassar: FKIP UNM.

Mbaco, N. (2013). Effect of Jigsaw Cooperative Learning Strategy on Students' Achievement in Secondary School Mathematics in Likipia Easr District Kenya. Asian Journal of Management Sciene and Education, 2(3), 177-188.

Nurhadi, Y.B. \& Senduk, A.G. (2004). Pembelajaran Kontekstual (Contextual Teahing and Learning/TCL) dan Penerapannya dalam KBK. http://library.um.ac.id. Diakses pada tanggal 19 Juli 2020 Pukul 21.00 WIB

Puspitasari, D. (2012). Hubungan Antara Persepsi Terhadap Iklim Kelas dengan Motivasi Belajar Siswa SMP Negeri 1 Bancak. EMPHATY. Jurnal Fakultas Psikologi, 1(1), 59-67.

Ramayulis. (2002). Metodologi Pengajaran Agama Islam. Jakarta: Kalam Mulian.

Rusman. (2012). Model-Model Pembelajaran. Jakarta: Rajawali Pers.

Sanusi, A. (2016). Metodelogi Penelitian. Jakarta: Salemba Empat.

Sardiman, A. (2008). Interaksi dan Motivasi Belajar Mengajar. Jakarta: Raja Grafindo Persada.

Seran, A. (2016). Penerapan Model Pembelajaran Kooperatif Tipe Jigsaw untuk Meningkatkan Motivasi dan Hasil Belajar pada Materi Pencernaan dan Kerusakan Lingkungan Kelas VIII B SMP Kansius Klasan Yogyakarta. Yogyakarta: Skripsi Program Studi Pendidikan Biologi Universitas Sanata Darma Yogyakarta.

Sumarsih dan Pardimin. (2017). Upaya Peningkatan Motivasi dan Prestasi Belajar IPA Melalui Penerapan Model Pembelajaran Jigsaw pada Siswa Kelas IX B SMPN 9 Yogyakarta. Jurnal Penelitian dan Evaluasi Pendidikan, 5(2), 123-134.

Tsay, M. \&. (2010). A Case Study of Cooperative Learning and Communication Pedagogy. Journal of The Scholarship of Teaching and Learning, 10(2), 78-89. 